\title{
Effect of Non-interest Income on Profitability of Deposit Money Banks in Nigeria
}

\author{
Olowolaju, Philip Segun
}

Department of Accounting, Federal University of Technology, Akure, Nigeria

Email:olowosegun2014@gmail.com Tel:08033524368

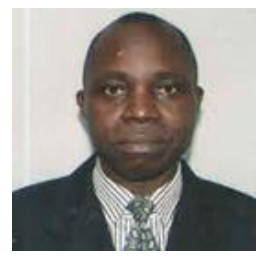

Check for updates

\begin{abstract}
The study examined the effect of non-interest income on the profitability of Deposit Money Banks (DMBs) in Nigeria between 2006 and 2015. Five out of the 21 DMBs in Nigeria were purposively selected based on the numerical strength of their customers, volume of transactions and geographical spread. Multiple regressions were used in analyzing the data. The result of the correlation shows that non-interest income and profit of Nigerian banks was found to be positive and significant at 0.05 level of significance with adjusted $\mathrm{R}=0.583$. However the growth rate of non-interest income has been inconsistent over the years. Liquidity ratio, prime lending rate and inflation are found to have no significant relationship with non-interest income. The study concluded that non-interest income has positive and significant effect on the profitability of DMBs in Nigeria. It is recommended that deposit money banks should be actively involved in customer analysis and market research in order to develop those products and services that will continually satisfy majority of their customers and also deploy effective and efficient technology that will ease banking transactions which the consumers will be willing to pay for so that high non- interest income can be generated.
\end{abstract}

Keywords: Non-interest income, Profitability, Deposit, Banks, Liquidity, Customers.

\section{Introduction}

Traditionally, banks are established to cater for the financial needs of the people in terms of deposit mobilization and asset generation which consequently impact the economy of the nation. Banks help in improving the efficiency of the entire economy, which makes it important for the banks to be profitable and remain evergreen. In other words, the banking sector is the engine of any nation's economy (Ndubuaku et al., 2017). Deposit money banks are service providers and in the provision of their services, customers may be satisfied and retained although profitability tends to be the result of good service delivery, yet every bank wants to be profitable. This quest for profitability has made the Nigerian banking system to be highly competitive.

Interest income has been the major contribution to the profitability of Nigerian banks until recently with the advent of technology which revolutionalise the banking operations in the country. Non-interest income in Nigerian banks has been limited to commission on turnover, fees and bank charges which tend to have little impact on the total profitability of the banks. However, with the introduction of liberalized banking, banks have been involved in different activities such as investments, trading and money transfer through which non-interest income is earned. With dwindling interest income from loans and advances, coupled with intense regulation from the Central Bank of Nigeria and stiff competition among deposit money banks, non-interest income has been put in the forefront as a major component of banks' total income.

However, things seem to be changing in the last decade when bankers are forced out of their comfort zone to do more than mobilise liability and book portfolio in order to remain in business. The need then arises for banks to be creative in income generation such that customer satisfaction is not adversely affected hence the introduction of non-traditional activities to earn non-interest income.

Good as profit making is, most account holders especially the high net-worth organizations and individuals often negotiate reduction in commission on turnover (COT) while others request for a reduction in the interest payable on loans (Agada, 2001). These activities are suggestive of the need for banks to find other avenues other than the traditional ways to increase profitability.

Furthermore, an increasingly open market and tough regulation have made it imperative for banks in China to source for non-interest income vigorously (Sun et al., 2017). The situation may not be totally different in Nigeria since the whole world is a global village where nations are interconnected economically. Thus, Nigerian deposit money banks face similar situations and the need to make profit by getting income from non-interest sources appears heightened. 
Meanwhile, Nigerian banks seem to pay competitive salaries, train their staff regularly and perform their statutory functions of paying tax to the coffers of government as at when due. At times, all levels of government would collect various levies from banks in addition to the social responsibility being rendered to their immediate communities.

All these services could be cost bearing which tend to impact on the bottom-line of the banks. Similarly, while shareholders are expectant of huge dividends as well as bonus shares at the end of the accounting year irrespective of the challenges facing the banks, investors on the other hand are studying the performance of these banks on the stock exchange which call for improved profitability. It tends to follow that while high performing banks' share price will be rising due to high return on investment, poor performers will be losing market. Therefore, each bank tries to remain strong in the market by finding different innovative ways of generating income aside from booking portfolio.

With the Asset Management Corporation of Nigeria (AMCON) liquidating banks carrying high toxic loans, many banks are taking calculated risks in creating assets thus reducing interest receivable from loans (Amakiri, 2016). The researcher further asserted that while banks could sell-off toxic loans to AMCON, banks will continue to be liable for defects in the toxic loan prior to AMCON's purchase. Perhaps others are afraid of prosecution by the Economic and Financial Crimes Commission (EFCC) in the event of their banks going under as a result of bad loans. Thus banks tend to focus non-interest generating activities.

Moreover, as the economy weakens, credit collection becomes seriously hampered especially when salaries remain unpaid as at when due, which implies possible escalation in loan loss provisioning for the banks. Worse still, providing for loan-loss in this era of economic recession seems to be death sentence for the banks and should be avoided hence the importance of non-interest income.

Also, the fall in the price of crude oil has impacted negatively on business activities, and most especially access of banks to foreign exchange to do business which has supposedly prompted customers to turn to neighbouring West African countries, countries like Ghana, Benin Republic and Togo where the import procedures and foreign exchange policy are friendlier (Onyenweaku, 2015). Therefore, profit generation through loans and foreign exchange sales are difficult.

Thus, it appears to be the conventional wisdom that non-interest income is more stable than interest income and that fee-based activities reduce bank risks through diversification (Köhler et al., 2013). With fee-based activities such as investments, trading and money transfer, revenues stemming from different products in a conglomerate organisation are usually imperfectly correlated.

According to Were and Wambua (2014) various types of interest rates were observed to have declined progressively since the 1990s up to the early 2000s in the commercial banks. This has brought the importance of non-interest income to deposit money banks' profitability to the fore since banks performance is important nationally and to the individual economic units because banks perform other functions in the larger economy (Wright, 2001).

Deposit money banks in Nigeria cater for the needs of their customers and make profit for their shareholders. Profitability has often been sourced through interest received on loans and advances. In recent times, interest income appears unattractive as a result of defaults in loan repayments and its consequences thereby making noninterest income the sought-after source of profitability.

The higher level of non-performing loans could perhaps be as a result of decline in economic growth caused by high inflation and economic instablity. Equally, the non-payment of salaries of government workers for many months adds to the economic challenges facing the banks because some of the civil servants owe banks through soft loans such as salary advance. Some staff cooperative societies could not get deductions from their unpaid salaries thus depriving the banks of deposit and in some cases; group loan repayment.

Furthermore, the importance of non-interest income to banks' profitability cannot be over-emphasized based on recent happenings in the country. With the implementation of the Treasury Single Account (TSA), which withdrew cheap government deposits in excess of N2.2 trillion Naira from the deposit money banks, loans and advances and deposit mobilization to the private sector had been adversely affected (Ndubuaku et al., 2017). Noninterest income generation appears to be insulated from issues limiting loans and deposit mobilization through which interest income is earned.

However, there is no consensus on the desirability of non-interest income over interest income as panacea to the profitability of deposit money banks due to contradictory findings that abound in literature globally. Although, there are studies on profitability of deposit money banks in Nigeria, few appear to deal with non-interest income and profitability.

What is not clear is whether non-interest income and interest income are related as well as the significant contribution of non-interest income to banks' profitability. Moreover, the growth rate of non-interest income in banks in the last ten years seems unclear hence the need for this study. This is because, when these factors are investigated, non-interest income generation may become the core income source for banks. On the other hand, examining the trend of non-interest income over ten years in the selected banks may reveal growth or reduction that calls for new strategies in product development and service delivery.

Moreover, literature on the contribution of non-interest income to banks performance or profitability in the developing and developed economies has been contradictory. One set of arguments hold that restricting banking scope to the traditional activities reduces likelihood of failure related to risk businesses, while the second set argues that non-interest income enhances bank profitability and reduces risk; the third set holds that impact of noninterest income on bank performance is uncertain (Sun et al., 2017). Therefore, this study investigated the relationship between non-interest income and profitability of Nigerian deposit money banks, perhaps as a way out of the myriad of challenges facing their profitability. 


\section{Literature Review}

\subsection{The Concept of Non-Interest Income}

Non-interest income is a financial concept that is usually associated with the banking sector. According to Smith, Staikouras and Wood (2003) non-interest income is defined as a mixture of heterogeneous components that differs in terms of their relative importance. These include deposit service charge, credit card fees, and fees associated with electronic funds transfer.

Stiroh (2004) opined that institutions charge fees that provide non-interest income as a way of generating revenue and ensuring liquidity in the event of increased default rates. Non-interest income makes up a significant portion of most banks' revenue.

There seems to be a close relationship between non-interest income and bank characteristics, market conditions, technological progress and bank performance.

In this view, well managed banks rely relatively less on non-interest income; whereas the banks which stress customer relationships and service quality tend to generate more non-interest income; and that the development of new financial technologies such as cashless transactions and mutual funds are associated with higher levels of non-interest income in the banking system.

Increases in non-interest income tend to be associated with higher profitability, higher variation in profits, and a worsened risk-return tradeoffs for the average commercial bank during specific periods of times (DeYoung and Rice, 2004).Smith et al. (2003) expressed that fee-earning income is less stabilising than generally believed; indeed, fee-earning income is actually more variable for most categories of banks than traditional interest income. It does, however, help in most cases to stabilise profit streams.

\subsection{The Concept of Profitability}

The word 'profitability' is composed of two words, namely; profit and ability. The term profit means the left over after cost has been deducted from revenue; where revenue is more than cost. The term ability indicates the power of a firm to earn profits. The ability of an enterprise also denotes its earning power or operating performance. So, on this basis profitability may be defined as the ability of a given instrument to earn a return from its use.. A bank is said to be 'profitable' if it can accrue financial gains from the capital invested into the operational activities of the bank. The success of a bank is determined by how well the bank made profits in the course of a financial period. For banks to be profitable, they have to assume a reasonable level of risk (Adeusi et al., 2014).

Likewise, Ayanda et al. (2013) refer to profitability as the ability of a business organization to maintain its profit year after year. The profitability of the organization will definitely contribute to the economic development of the nation by way of providing additional employment and tax revenue to government exchequer. Moreover, it will contribute the income of the investors by having a higher dividend and thereby improve the standard of living of the people.

Osuagwu (2014) opined that bank profitability is an important ingredient of financial development, its relevance spans through banking firms' performance to macroeconomic stability. At the firm level, a higher return to a large extent reduces bank fragility. At the macro level, increased profitability makes for a sustainable banking sector that can finance economic growth and development.

\subsection{Components of Non-Interest Income}

Non-interest income refers to banks' earnings from non-traditional banking activities such as Commission, charges and other related fees. These enter into the composition of interest margins for banks. According to noninterest income is bank and creditor income derived primarily from fees including deposit and transaction fees, insufficient funds (NSF) fees, annual fees, monthly account service charges, inactivity fees, check and deposit slip fees, and so on. Institutions charge fees that provide non-interest income as a way of generating revenue and ensuring liquidity in the event of increased default rates. Credit card issuers also charge penalty fees, including late fees and over-the-limit fees, commissions and fee.

Non-interest income includes service charges on loans and transactions, commissions and other operating income. The commissions and fees included in the non-interest income and the income from transactions involving foreign exchange reported in the interest income section of the profit or loss accounts of banks are inclusive of receipts from related off-balance sheet activities. Non-interest expenses include service charges and commissions, expenses associated with fixed assets and general management affairs, salaries and other expenses (Baltagi, 2005). Total deposits are deposits and purchased funds for bank operations and the sources of loanable funds for investment.

\subsection{Factors Influencing Non-Interest Income}

There are four main factors that could have led to growth in non-interest income in the banking industry worldwide. These are deregulation, supervision, globalization and rapid technological advances in information flows, communications infrastructure and financial markets. Banking industry deregulation fosters competition between banks, non-banks and financial markets by removing restrictions that stunt the evolution of the banking system, constrain the efficiency of the financial product markets and extend the lives of poorly run or sub-optimalsized deposit money banks (DeYoung and Rice, 2004).

Advances in information and communications technology (for example, the Internet and Automatic Telling Machines (ATMs)), new intermediation technologies for processes like loan securitization and credit scoring, and the introduction and expansion of financial instruments and markets (high yield bonds, commercial paper, financial derivatives) all impacted on the levels and types of non-interest income of deposit money banks. These appeared to have been helped by the process of deregulation. In essence, these changes meant that banks could extract fee income from customers who were willing to pay for use of ATMs and /or the Internet rather than undertake business at traditional branches. In addition, loan securitization enabled banks to better leverage their equity capital by moving loans off statement of financial position. By reducing the amount of deposit 
funding necessary to originate a dollar's worth of new loans, loan securitization decreases the importance of intermediation in favour of non-interest income (loan origination and servicing fees). Moreover, greater access to the commercial paper market, although depriving larger banks of large denomination, high quality, short term, commercial loans, allowed them to earn fee income from providing back-up lines of credit that firms need to float commercial paper. An additional overarching factor that may have led to an increase in non-interest income worldwide is the introduction of the new regulatory requirements - Basel I and Basel II, the latter still to be finalized. According to these capital requirements, drawn up by the Bank of International Settlements, can positively affect the cost of capital and compliance of banks. Consequently, banks have to look more closely at the different assets on their books and price them accordingly. A further force impacting on non-interest income is globalization that, in some cases, has led to mergers and acquisitions.

\subsection{Non-Interest Income and Banks' Profitability}

An increase in non-interest income improves bank earnings, an increase in non-interest income seldom occurs without associated changes in interest income, variable inputs, fixed inputs, and financing structure (Feldman and Schmidt, 1999). It was conventionally believed that expansion into new fee-based products and services reduced earnings volatility via diversification effects. Therefore having products that attract a significant amount of fees contribute to the financial performance of a commercial bank. Some researchers deem that non-interest income business can improve the total income, since banks can expand the source of income by diversifying income.

According to Sun et al. (2017) noninterest income can increase the total level of income of commercial banks in several ways: (1) satisfying diversified needs for financial services, investment consultation, and so forth by continuous innovation of new financial products and services in order to gain more fees and commission and strengthen the market competitiveness; (2) improving the investment level of commercial banks in financial markets to gain the investment income from bonds and stocks; (3) enriching income from gains or losses of exchange and profits or losses from changes of fair value and other business. They concluded that noninterest income increases volatility of bank earnings and increases operating risk such that overall income can increase in the initial stage of development but the marginal income of noninterest income will decrease and the rising operating costs will decrease the net income. Brunnermeier et al. (2015) reveals that banks' non-interest income either from trading income or venture capital income is related to systemic risk in the United States of America.

\section{Methodology}

The study used the ex-post facto research design of the survey type owing to its capability to address the objective of the study. This explanatory study was based on secondary data obtained from published financial statements of deposit money banks in Nigeria.

The population of this study was the entire twenty one licensed deposit money banks in Nigeria. All these deposit money banks have branches distributed all over Nigeria. Five out of twenty one banks were selected through purposive sampling which is a non-probability sampling technique. The selection criteria are that the banks are large and are national banks with presence all over the country, availability of consistent data-set over the period covered in the study large customers' base and diversified customers service. Equally, the banks are listed on the Nigeria Stock Exchange. The period cover by the study is 2006 to 2015

Panel regression model was used to determine the effect of non-interest income of the DMBs' profitability. However, other variables such as liquidity ratio, inflation rate and prime lending rate which also influence the profitability of Banks were considered in the model for the study The regression model used for this study was as follows;

$\mathrm{PBT}=\mathrm{f}(\mathrm{NII})$

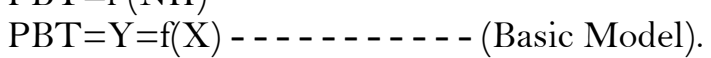

$\mathrm{PBT}=\mathrm{Y}=\beta_{0}+\beta 1 \mathrm{X} 1+\beta 2 \mathrm{X} 2+\beta 3 \mathrm{X} 3+\beta 4 \mathrm{X} 4+\dot{\varepsilon}$

$=\beta+\beta_{1} \mathrm{NII}+\beta_{2} \mathrm{LR}+\beta_{3} \mathrm{PLR}+\beta_{4} \mathrm{INF}+\dot{\varepsilon}$

Where;

Profitability $($ PBT $)=$ Profit before Tax

$\mathrm{NII}=$ Total noninterest income

$\mathrm{LR}=$ Liquidity Ratio

PLR = Prime Lending Rate

$\mathrm{INF}=$ Inflation (Yearly average rate).

$\dot{\varepsilon}=$ Error term.

$\beta_{0}=$ Regression Constant term and,

$\beta_{1}, \beta_{2}, \beta_{3}, \beta_{4}=$ Regression coefficients of the variation to determine the volatility of each variable to banks profitability in the regression model

\section{Results and Discussion}

The main objective of the study was to establish the relationship between non-interest income and profitability of deposit money banks in Nigeria. Data were collected from the financial statements of the five selected deposit money banks from the Nigeria Stock Exchange, Lagos for a period of ten years giving a total of fifty (50) observations.

The selected deposit money banks were:

First Bank PLC; Access Bank PLC; Guaranty Trust Bank PLC; Fidelity Bank PLC; and Zenith Bank PLC. The data collected were analyzed and the results were presented and discussed.

Table 4.1 reveals the results of correlation matrix among variables. The correlation matrix helps to ascertain the extent of relationship existing amongst the dependent and independent variables. It also ascertains the extent of relationship amongst the variables. The relationship between the dependent and independent variables is a 
predetermination of how the regression result would look like. From the table, the result of the correlation shows that non-interest income is significantly and positively correlated with interest income, indicating that there is a relationship between, interest income and non-interest income, though not a causal relationship. From the table, the significant value $\mathrm{p}=(0.000)$ is less than $0.01(</=0.01)$, (Confidence level) .

The Pearson Correlation value $(\mathrm{r})$ is 0.723 , which indicated that there is a strong positive relationship between non-interest income and interest income of DMBs to the tune of $72.3 \%$. This could be indicative of the fact that non-interest income in the Nigerian banking industry is co-existing with interest income. These findings are generally in line with the findings of Rogers and Sinkey (1999) who asserted that collectively, banks with high levels of non-traditional activities tend to be safer, indicating some amount of market discipline.

All the five deposit money banks selected for the study were found to be actively involved in generating noninterest income through various means but under different nomenclature. The reviewed literature has revealed that non-interest income sources are fee based income, fund transfer income, investment and trade income, ATM charges, sale of cheque books, other stationeries, statement of account charges, safe keep and many others related fees

Furthermore, literature reviewed on the study showed that banks' profitability could be influenced by other variables such as inflation rate (INF), prime lending rate (PLR) and liquidity ratio (LR) and Prime lending rate. The study also examined the effect of these variables on profitability of DMB. These variables also have some effect on banking performance (profitability) and its spillover effect on the overall economy (Umar et al., 2014). However, results from Table 4.2 shows that the non-interest income of the deposit money banks has a non-significant relationship with inflation rate, prime lending rate and liquidity ratio with significant values of $0.761,0.349$ and 0.755 in that order. This implies that the inflation rate, prime lending rate and liquidity ratio of the selected deposit money banks do not significantly determine its non- interest income and profitability, as there could be other factors that contribute significantly to it other than these factors. This finding is similar to the study made by Kosmidou (2008) and Ghazali (2008) which showed that the result of liquidity influence on profitability is mixed and they found that the impact of liquidity is not straight forward, as higher level of liquidity tends to be converted into current assets which are idle assets and therefore need to be balanced.

In addition, Table 4.2 shows that there is a significant relationship between non-interest income and profit before tax of DMBs. The Pearson Correlation value $(r)$ is 0.769 , which indicate that there is a strong positive relationship between non-interest income and profit before tax of DMBs. This means that an increase in noninterest income may also lead to an increase in profit before tax of DMBs in Nigeria to the tune of 76.9\%.All the sampled banks did not do comprehensive classification of the components of their non-interest income. Perhaps, this was done strategically for competitive advantage in a highly volatile and sensitive financial market. The nonspecific classification of non-interest income by Nigerian banks is similar to what operates in the United States of America where non-interest income generally come under fee based income, investment and trade income among others (Muckian, 2014).

Table-4.1. Correlation Results of the Relationship between Non-Interest Income and Interest Income of DMBs in Nigeria

\begin{tabular}{l|l|l|l}
\hline & & Non-Interest Income & Interest Income \\
\hline & Pearson Correlation & 1 & $0.723^{* *}$ \\
\hline Non-Interest Income & Sig. (2-tailed) & & 0.000 \\
\hline & $\mathrm{N}$ & 50 & 50 \\
\hline & Pearson Correlation & $0.723^{* *}$ & 1 \\
\hline Interest Income & Sig. (2-tailed) & 0.000 & \\
\hline & $\mathrm{N}$ & 50 & 50 \\
\hline
\end{tabular}

*** Correlation is significant at the 0.05 level (2-tailed).

Source: Field Survey, 2018

Table-4.2. Correlation Results of the Relationship between Non-Interest Income, Inflation Rate, Lending Prime Rate, Liquidity Ratio and Profit Before Tax of DMBs in Nigeria

\begin{tabular}{l|l|l|l|l|l}
\hline & & Inflation Rate & $\begin{array}{l}\text { Prime } \\
\text { Lending Rate }\end{array}$ & $\begin{array}{l}\text { Liquidity } \\
\text { Ratio }\end{array}$ & Profit Before Tax \\
\hline \multirow{2}{*}{$\begin{array}{l}\text { Non-Interest } \\
\text { Income }\end{array}$} & Pearson Correlation & -0.044 & -0.135 & -0.045 & $0.769^{* *}$ \\
\cline { 2 - 6 } & Sig. (2-tailed) & 0.761 & 0.349 & 0.755 & 0.000 \\
\cline { 2 - 6 } & $\mathrm{N}$ & 50 & 50 & 50 & 50 \\
\hline
\end{tabular}

**. Correlation is significant at the 0.01 level (2-tailed).

Source: Field Survey, 2018

\subsection{Regression Output of Profitability of Dmbs on Inflation, Prime Rate, Liquidity Ratio and Non-Interest Income}

A regression analysis of profitability of deposit money banks as dependent variable on the independent variables (Total Non-interest Income, Liquidity Ratio, Prime Lending Rate and Inflation) was carried out to show the combined predictive effect of the independent variables on the dependent variable and also the variability in the dependent variable contributed by each of the independent variables. Multiple $\mathrm{R}$ is an indicator of how well the overall regression equation predicts the observed data. The model summary (Table 4.3) shows multiple $\mathrm{R}$ has value, 0.784 which indicates that the linear combination of the three independent variables (Total Non-interest Income, Liquidity Ratio, Prime Lending Rate and Inflation) strongly predicts the actual dependent variable (profitability). $\mathrm{R}$ Square is the measure of the proportion of variance that can be explained in the dependent variable by the linear combination of the independent variables. The values of $\mathrm{R}^{2}$ also range from $\mathrm{O}$ to 1 . The result of the analysis presented in Table 4.5 suggests that the linear combination of total non-interest income, liquidity ratio, prime lending rate and inflation for the banks explains 61.5 percent of the changes in profitability. The remaining 38.5 percent is explained by variable(s) alien to the model. 
The table labelled ANOVA in Table 4.4 provides the results of a test of significance for $\mathrm{R}$ and $\mathrm{R}$ square using the F-statistic. In this analysis, the p-value is well below $0.05(\mathrm{p}<.000)$, and therefore, we can conclude that $\mathrm{R}$ and $\mathrm{R}^{2}$ for the multiple regression conducted predicting profitability based on the linear combination of total noninterest income, liquidity ratio, prime lending rate and inflation is statistically significant.

The multiple regression coefficients output is as presented in Table 4.5. Under the column marked Unstandardized Coefficient and sub-column B is the value for the intercept (a)in the regression equation on the first row, labelled (Constant). The numbers below it in the same column are the values for the regression coefficients total non-interest income, liquidity ratio, prime lending rate and inflation. Based on these results, the regression equation that predicts profitability based on the linear combination of total non-interest income, liquidity ratio, prime lending rate and inflation is as follows:

$P B T=-37496.30+1.255 \mathrm{NII}+553.12 \mathrm{LR}-764.88 \mathrm{PLR}+1617.96 \mathrm{INF}$

This result indicates, first, that the intercept is -37496.30 when all independent variables have a value of zero. Moving through the equation; holding liquidity ratio, prime lending rate and inflation constant, the profitability increase by 1.255 for each additional increase in the total non-interest income. The p-value for this coefficient is statistically significant $(\mathrm{p}<0.001)$, meaning that non-interest income is a significant predictor of profitability. Holding other independent variables constant, liquidity ratio, prime lending rate and inflation individually increase, decrease and increase profitability by $553.12,-764.88$ and 553.119 correspondingly for each additional increase in each of the predictors but these coefficients are not statistically significant ( $p=0.301,0.835$, and 0.158 ). Liquidity ratio, prime lending rate and inflation are individually not a significant predictor of the profitability.

Table-4.3. Model Summary of Profitability of DMBs on Inflation, Prime rate, Liquidity ratio and Non-interest income

\begin{tabular}{l|l|l|l|l}
\hline Model & R & R Square & Adjusted R Square & Std. Error of the Estimate \\
\hline 1 & $0.784^{\mathrm{a}}$ & 0.615 & 0.581 & 22667.6013 \\
\hline
\end{tabular}

\begin{tabular}{|c|c|c|c|c|c|c|}
\hline Model & & Sum of Squares & Df & Mean Square & $\mathbf{F}$ & Sig. \\
\hline \multirow[t]{3}{*}{1} & Regression & 36919096124.297 & 4 & 9229774031.074 & 17.963 & $0.000^{b}$ \\
\hline & Residual & 23121906704.023 & 45 & 513820148.978 & & \\
\hline & Total & 60041002828.320 & 49 & & & \\
\hline
\end{tabular}

a. Dependent Variable: DMB_PBT

b. Predictors: (Constant), DMB_NII, inflation, Prime Rate, liquidity Ratio

Source: Field Survey, 2018

Table-4.5. Multiple Regression Analysis of Profitability of DMBs on Inflation, Prime rate, Liquidity ratio and Non-interest income

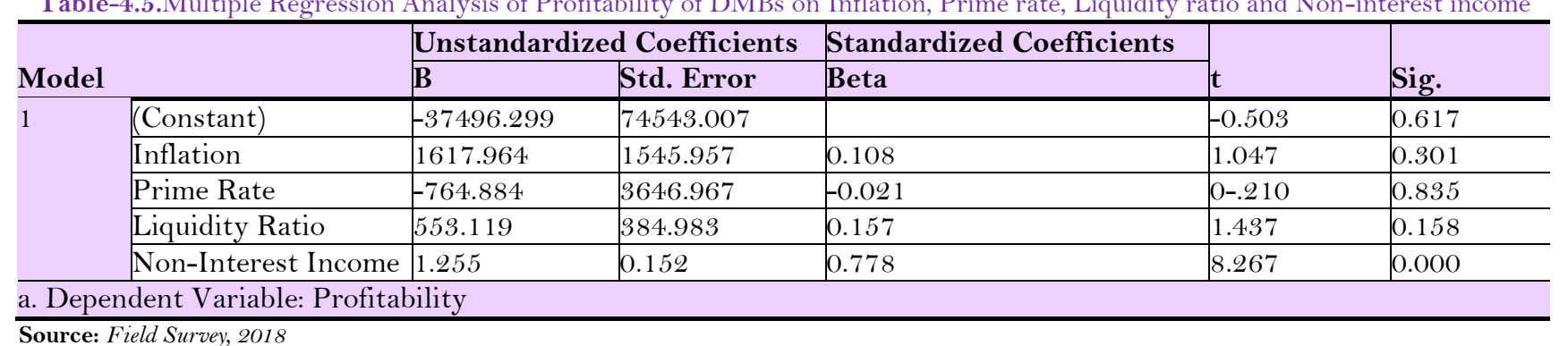

Source: Field Survey, 2018

The Model Summary table (Table 4.6) presents the overall effect of non-interest income on profitability of DMBs in Nigeria. In this case, due to the small sample size, the Adjusted R Square is reported in place of the $\mathrm{R}$ square value. As shown, this tells how much of the variance in the dependent variable (profitability of DMBs) is explained by the model (which includes non-interest income). In this case, the value is 0.583 , this means that noninterest income explains 58.3 per cent of the variance in profitability of DMBs. This effect is found to be significant as shown by the Sig. value $(\mathrm{p}<0.05)$. Furthermore, non-income interest contributes about $76.9 \%$ to profit before tax of DMBs, which is found to be statistically significant as shown on Table 4.7. The coefficient of non-interest income was positive and this implies that as the non-interest income of the deposit money bank increases, their profitability also increases.

\begin{tabular}{l|l|l|l|l}
\multicolumn{5}{c}{ Table-4.6. Model Summary of the Effect of Non-Interest Income on Profitability of DMBs } \\
\hline Model & R & R Square & Adjusted R Square & Std. Error of the Estimate \\
\hline & $0.769^{\text {a }}$ & 0.591 & 0.583 & 22613.816 \\
\hline
\end{tabular}

Table-4.7. Regression Results of the Effect of Non-interest Income on Profitability of DMBs

\begin{tabular}{|c|c|c|c|c|c|c|}
\hline \multirow[b]{2}{*}{ Model } & & \multicolumn{2}{|c|}{ Unstandardized Coefficients } & \multirow{2}{*}{\begin{tabular}{|l|} 
Standardized Coefficients \\
Beta
\end{tabular}} & \multirow[t]{2}{*}{ t } & \multirow[t]{2}{*}{ Sig. } \\
\hline & & B & Std. Error & & & \\
\hline \multirow[t]{2}{*}{1} & (Constant) & -8903.350 & 6590.594 & & -1.351 & 0.183 \\
\hline & DMB_NII & 1.241 & 0.149 & 0.769 & 8.331 & 0.000 \\
\hline
\end{tabular}

\section{Summary of Findings}

The research results as presented above brought about the following findings which were discussed thus. Firstly, the result of the correlation analysis shows that non-interest income is significantly and positively correlated with interest income, though not a causal relationship. 
The Pearson Correlation value ( $\mathrm{r}$ ) is 0.723 , shows a strong positive relationship between non-interest income and interest income of DMBs to the tune of 72.3\%.; perhaps non-interest income in the Nigerian banking industry is co-existing with interest income. The finding is in line with the findings of Stiroh (2002) that non-interest income has become more correlated with net interest income.

Secondly, the findings of the study indicate that there is a significant relationship between non-interest income and profit before tax of DMBs.

The Pearson Correlation value (r) is 0.769 shows a strong positive relationship between non-interest income and profit before tax of DMBs. This means that an increase in non-interest income may also lead to an increase in profit before tax of DMBs in Nigeria to the tune of $76.9 \%$. This is in agreement with the findings of Sanya and Wolfe (2011) that studied 226 listed banks in emergent economies from 2000 to 2007 and reported that diversification decreases insolvency risks and enhances profitability. It is in consonance with the findings of Feldman and Schmidt (1999) that the profit of the bank depends mostly on noninterest income but not interest income as people generally expect.

Similarly, Rogers and Sinkey (1999) showed that collectively, banks with high levels of non-traditional activities tend to be safer, indicating some amount of market discipline. In contrast with the findings of this study, Sun et al. (2017) found that there is non-linear relationship and a general negative correlation between no (2011) show that long time focusing on non-interest income generates volatility of bank earnings, increased operating risk and requirement of higher management ability. In disagreement to the findings of this study, Stiroh and Rumble (2006) show that noninterest income unfavourably affects bank performance by either reducing return or increasing income volatility and there is no significant correlation between the noninterest income and the average rate of return. Smith et al. (2003) show that the increase of noninterest income cannot totally cover the income reduction, meaning that non-interest income cannot offset income reduction.

Furthermore, in disagreement to the findings of this study, Gamra and Plihon (2011) found that diversification gains are more than offset by the cost of exposure to the noninterest income due to income volatility and that diversification performance's effect is found to be no linear with risk, and significantly not uniform among banks. They concluded that banks can reap diversification benefits as long as they are well studied based on the banks specific characteristics, competences, risk levels and choice of the right niche.

\section{Conclusion and Recommendations}

\subsection{Conclusion}

The findings from this study showed that non-interest income has positive and significant relationship with deposit money banks' profitability. Also, the growth rate of non-interest income has been inconsistent in all the selected banks probably due to government fiscal and tax policies. Although banks are striving to develop innovative products and services for generating non-interest income, yet interest income cannot be totally neglected as it still plays a major role in banks' profitability.

\subsection{Recommendations}

Based on the findings of this study, it is recommended that:

i. Deposit money banks should be actively involved in customer analysis and market research in order to develop those products and services that will continually satisfy majority of their customers so that high non- interest income can be generated.

ii. It is recommended that deposit money banks should further deploy effective and efficient technology that will ease banking transactions which the consumers will be willing to pay for.

iii. Customers should not be overburdened with fees but can be spread over all customers and their loyalty will still be obtained and retained.

\section{References}

Adeusi, S.O., T.F. Kolapo and A.O. Aluko, 2014. Determinants of commercial banks' profitability panel evidence from Nigeria. International Journal of Economics, Commerce and Management, 2(12): 1-18.

Agada, S., 2001. Nigeria: Bankers fault cot fee. Lagos: Financial Standard.

Amakiri, D.Y., 2016. AMCON, banks and bank debtors: Liability for defects in non- performing loans. Available from Nigerianlawtoday.com/amcom-banks and bank debtors [Accessed 16/10/2017].

Ayanda, A.M., E.I. Christopher and M.A. Mudashiru, 2013. Determinants of banks' profitability in developing economy: Evidence from Nigerian banking industry. Interdisciplinary Journal of Contemporary Research in Business, 4(9): 163-176.

Baltagi, B., 2005. Econometric analysis of panel data. New Jersey: John Wiley and Sons.

Brunnermeier, M.K., G. Dong and D. Palia, 2015. Banks' non-interest income and systemic risk. New Jersey: Princeton Publication.

DeYoung, R. and T. Rice, 2004. Noninterest income and financial performance at US commercial banks. Financial Review, 39(1): 101-127. Available at: https://doi.org/10.1111/j.0732-8516.2004.00069.x

Feldman, R. and J. Schmidt, 1999. Noninterest income: A potential for profits, risk reduction, and some exaggerated claims. The Federal Reserve Bank of Minneapolis, Fedgazette. October Issue. pp: 20-21. Available from https://.ideas.repec.org/a/fip/fedmga/y 1999iocp20-21 nv1 1 no4.html.

Gamra, S.B. and D. Plihon, 2011. Revenue diversification in emerging market banks: Implications for financial performance. CEPN Working Papers. [Accessed 12/10/2107].

Ghazali, M., 2008. The bank-specific and macroeconomic determinants of islamic bank profitability: Some international evidence. The BankSpecific and Macroeconomic Determinants of Islamic Bank Profitability:Some International Evidence. Available from http://dspace.f sktm.um.edu.my/bitstream/1812/752/1/abstract.pdf [Accessed 15November 2016].

Köhler, M., K. Düllmann, H. Herrmann and C. Memmel, 2013. Does non-interest income make banks more risky?. Discussion Paper, Deutsche Bundes Bank, Frankfurt am Main No 17/2013.

Kosmidou, K., 2008. The determinants of banks profits in Greece during the period of EU Financial integration. Journal of Managerial Finance, 34(3): 146-159. Available at: https://doi.org/10.1108/03074350810848036.

Muckian, M., 2014. Ways to increase non-interest income. Available from www.cutimes.com/2014/05/16/5ways [Accessed February $21,2017]$.

Ndubuaku, V., O. Ohaegbu and N. Nina, 2017. Impact of treasury single account on the performance of the banking sector in Nigeria. IOSR Journal of Economics and Finance, 8: 8-15. Available at: https://doi.org/10.9790/5933-0804010815.

Onyenweaku, O., 2015. Nigerians mop up dollars across West Africa. Business Hallmark. 
Osuagwu, E.S., 2014. Determinants of bank profitability in Nigeria. International Journal of Economics and Finance, 6(12): 1916-9728. Available at: ttps://doi.org/10.5539/ijef.v6n12p46.

Rogers, K. and J.J.F. Sinkey, 1999. An analysis of nontraditional activities at US commercial banks. Review of Financial Economics, 8(1): 2539. Available at: https://doi.org/10.1016/s1058-3300(99)00005-1.

Sanya, S. and S. Wolfe, 2011. Can banks in emerging economies benefit from revenue diversification? Journal of Financial Services Research, 40(1-2): 79-101. Available at: https://doi.org/10.1007/s10693-010-0098-z.

Smith, R., C. Staikouras and G. Wood, 2003. Non-interest income and total income stability. Working Paper 198. Bank of England.

Staikouras, C. and G. Wood, 2003. Non-interest income and total income stability. Manuscript statistical abstract. Uganda Bureau of Statistics.

Stiroh, K., 2004. Diversification in banking: Is noninterest income the answer? Journal of Money, Credit and Banking, 36(5): 853-882. Available at: https://doi.org/10.1353/mcb.2004.0076.

Stiroh, K.J., 2002. Diversification in banking: Is non-interest income the answer? Federal Reserve Bank of New York Staff Report, 154: 1-26.

Stiroh, K.J. and A. Rumble, 2006. The dark side of diversification: The case of US financial holding companies. Journal of Banking \& Finance, 30(8): 2131-2161. Available at: https://doi.org/10.1016/j.jbankfin.2005.04.030.

Sun, L., S. Wu, Z. Zhu and A. Stephenson, 2017. Noninterest income and performance of commercial banking in China. Scientific Programming, 2017(1): 8. Available at: https://doi.org/10.1155/2017/4803840.

Umar, M., D. Maijama'a and M. Adamu, 2014. Conceptual exposition of the effect of inflation on bank performance. Journal of World Economic Research, 3(5): 55-59. Available at: https://doi.org/10.1 1648/j.jwer.20140305.11.

Were, M. and J. Wambua, 2014. What factors drive interest rate spread of commercial banks? Empirical evidence from Kenya. Review of Development Finance, 4(2): 73-82. Available at: https://doi.org/10.1016/j.rdf.2014.05.005.

Wright, R.E., 2001. Origins of commercial banking in America, 1750-1800. New York: Rowman \& Littlefield Publishers. pp: 19-27.

Citation | Olowolaju, Philip Segun (2018). Effect of Non-interest Income on Profitability of Deposit Money Banks in Nigeria. Journal of Banking and Financial Dynamics, 2: 1-8.

\section{History:}

Received: 12 September 2018

Revised: 15 October 2018

Accepted: 21 November 2018

Published: 17 December 2018

Licensed: This work is licensed under a Creative Commons

Attribution 3.0 License (cc) EY

Publisher: Eastern Centre of Science and Education
Funding: This study received no specific financial support.

Competing Interests: The author declares that there are no conflicts of interests regarding the publication of this paper.

Transparency: The author confirms that the manuscript is an honest, accurate, and transparent account of the study was reported; that no vital features of the study have been omitted; and that any discrepancies from the features of the study have been omittion
study as planned have been explained.

Ethical: This study follows all ethical practices during writing.

Eastern Centre of Science and Education is not responsible or answerable for any loss, damage or liability, etc. caused in relation to/arising out of the use of the content. Any queries should be directed to the corresponding author of the article. 